\title{
Ecological Risks Assessment and Pollution Source Identification of Trace Elements in Contaminated Sediments from the Pearl River Delta, China
}

\author{
Feng Li • Xiang-yun Zeng • Chang-hua Wu • \\ Zhi-peng Duan • Yan-mao Wen • Guo-ru Huang • \\ Xiao-lin Long • Min-Jian Li • Man-Jie Li • Jiang-Yu Xu
}

Received: 6 December 2012 / Accepted: 7 August 2013 / Published online: 23 August 2013

(C) The Author(s) 2013. This article is published with open access at Springerlink.com

\begin{abstract}
Sediments from 14 stations in the Foshan Waterway, a river crossing the industrial district of Guangdong Province, South China, were sampled and subsequently analyzed. The 14 stations were selected for the pollution discharging features of the river, such as the hydrology, the distribution of pollution sources, and the locations of wastewater outlets. The ecological risks were assessed, and the pollution sources were identified to provide valuable information for environmental impact assessment and pollution control. The spatial variability was high and the range were (in milligrams per kilogram dry weight): $\mathrm{Pb}$, 46.0 382.8; $\mathrm{Cu}, 33.7 \sim 482.3 ; \mathrm{Zn}, 62.2 \sim 1,568.7$; Ni, 28.5 130.7; Cr, 34.7 1,656.1; Cd, 0.50 8.53; Hg, 0.02 8.27; and As, 5.77 66.09. The evaluation results of enrichment factor and potential ecological risk index indicate that the metal pollution in the surface and bottom sediments were severely polluted and could pose serious threat to the ecosystem in most stations. Although the hazard levels of the trace element differed among the stations, $\mathrm{Hg}$ was the most serious pollutant in all stations. The results of principal component analysis (PCA) show that the discharge of industrial wastewater is the most important polluting factor whereas domestic sewage, which
\end{abstract}

Electronic supplementary material The online version of this article (doi:10.1007/s12011-013-9789-2) contains supplementary material, which is available to authorized users.

F. Li $(\bowtie) \cdot$ X.-y. Zeng · C.-h. Wu • Z.-p. Duan · G.-r. Huang •

X.-1. Long $\cdot$ M.-J. Li $\cdot$ M.-J. Li $\cdot$ J.-Y. Xu

School of Civil Engineering, South China University of Technology,

Guangzhou 510641, China

e-mail: hjlifeng@scut.edu.cn

Y.-m. Wen

The Institute of Environmental Science, Sun Yat-sen University, Guangzhou 510275, China contains a large amount of organic substances, accelerates metal deposition. And potential pollution sources were identified by the way of integrating the analysis results of PCA and data gained from the local government. Therefore, the conclusion is drawn that Foshan Waterway is seriously polluted with trace elements, both in the surface sediment $(0$ to $20 \mathrm{~cm})$ and the bottom sediments (21 to $50 \mathrm{~cm}$ ) are contaminated.

Keywords Ecological risks assessment - Trace elements . Enrichment factor (EF) · Potential ecological risk index · Principal component analysis (PCA) · Pollution source identification

\section{Introduction}

The toxicity of trace metals has long been a concern considering they are not removed from aquatic ecosystems by selfpurification [1] and accumulate in suspended particulates and sediments $[2,3]$, thereby potentially threatening human health and ecosystems via the food web [4-6]. Consequently, evaluating ecological risk from trace elements has become a hot topic [7-9]. Concentrations of $\mathrm{Cd}, \mathrm{Cu}, \mathrm{Ni}, \mathrm{Pb}, \mathrm{Zn}$, and other metals are often elevated above crustal (background) levels in sediments that have been affected by human activities [10, 11], particularly from mining and smelting waste sites [12-17]. In rivers, trace elements can be transported hundreds of kilometers along hydrologic gradients within a relatively short time [18-20]. Moreover, trace elements are released in both dissolved and particulate forms [9, 21, 22]. When released in particulate form or adsorbed onto particles, trace elements settle and are deposited in the bottom river sediments under favorable hydraulic conditions [23-25]. Therefore, sediments, which act as both carriers and sinks for contaminants, 
play a major role in determining the pollution pattern of aquatic systems [26-29], reflecting the history of pollution [30-32] and providing a record of catchments inputs into aquatic ecosystems [33-35].

Numerous methods for assessing heavy metal toxicity have been created and used in the past decades, [36-41]. Enrichment factors [42], geoaccumulation index, and Hakanson potential ecological risk assessment are frequently used for assessing polluted rivers [43-46]. For example, Lourĩno-Cabana (2011) [47] evaluated the potential sediment cumulative damage and toxicity due to metal contamination in a polluted zone of Deûle river (in northern France) using metal enrichment factors and geoaccumulation index, and this same method was used to evaluate the metal pollution status of the surface sediments of the Seyhan Dam reservoir in Turkey [48]. Metal enrichment factors and the geoaccumulation index were also employed in the analysis of the metal contamination in surface sediments (0 to $5 \mathrm{~cm})$ from 59 stations within the Yangtze River Intertidal Zone (YRIZ) [49]. An ecological risk assessment was conducted based on the data analysis of the contents of typical pollutants $(\mathrm{Pb}, \mathrm{Cu}, \mathrm{Cr}, \mathrm{Cd}$, and $\mathrm{Zn})$ in the sediments of the Yangtze River within the Wanzhou section [50]. These methods have different features, applicable range, and limitations [51-53]. However, few studies combine these methods to comprehensively evaluate the trace elements in sediments. Multivariate statistical study has been introduced to determine the background and anthropogenic influence of metals on river sediments $[52,54,55]$. PCA, a commonly used multivariate analysis method, facilitates the study of trace elements in river sediments: it has been applied to interpret the variations in trace metals and organic matter concentrations in sediment samples to assist in identifying possible pollution sources with the spatial distribution of trace elements in river sediments, and to establish the correlations between any two binding fractions of trace elements $[46,49,53,56]$.

The Pearl River Delta (PRD) in Guangdong Province, with a densely crisscrossing river network, is one of the most abundant water resource areas in China [46]. Since China implemented reforms and opening up policy, this area has experienced rapid economic and social development, and has become a worldwide manufacturing base. However, large amounts of industrial wastewater and domestic sewage are directly discharged into the river, which exerts great environmental pressure and causes the degradation of the PRD and its tributaries, even threatening the safety of drinking water sources. Especially in recent years, several severe heavy metal contamination accidents have endangered the downstream drinking water sources of millions of people. The Foshan Waterway, a typical river in the PRD, flows through the densely populated and developed industrial district of Foshan. Its environmental quality has drawn wide attention because it links Beijiang River (an important drinking water source) and the Guangzhou section of the Pearl River (one of the drinking water sources of Guangzhou). In the past years, local government has made a huge investment (partly from the World Bank loans) in river rehabilitation to ensure the safety of drinking water, but failed to achieve the desired results. According to the limited information available, dredging of the Foshan Waterway was proposed because of its severe sediment contamination. Contaminant remediation through dredging is very costly [57] and the negative impact of dredging is obvious, for example, the physical disturbance of metalpolluted sediments may pose severe risks to the aquatic environment through increased metal remobilization and habitat deterioration [58]. Therefore, dredging should not be carried out if heavy metal pollution in sediment is not particularly serious, and then, determining the content, spatial distribution of trace elements, and accurately assessing the ecological risk are crucial. Furthermore, there is a choice between shallow dredging (dredging depth is $20 \mathrm{~cm}$ ) and deep dredging (dredging depth is $50 \mathrm{~cm}$ ). Shallow dredging is more economical, but inadequate, when the bottom sediment has been polluted. Therefore, a comprehensive ecological risk assessment is badly needed. In addition, potential heavy metal sources should be identified to manage them appropriately. In this study, sediments from 14 stations in the Foshan Waterway were sampled and analyzed to conduct an integrated ecotoxicological assessment. Moreover, multivariate statistical analysis was carried out to help identify the sources of trace metals.

The present study has been initiated with the following objectives: (1) to determine the levels of trace elements contamination and the spatial distribution of them along the Foshan Waterway; (2) to evaluate potential ecological risks from metal pollution using a variety of methods and to compare the results; in particular, the risks involving the lower layer sediments; (3) to identify the sources of heavy metal contamination and to determine the causes of pollution. The results of this investigation would have implications in the development of a rational rehabilitation method for the Foshan Waterway. In addition, such a scientific and preventive approach based on a better understanding of the source, fate, and effects of metal contaminants in aquatic systems would be of great interest in the development of pollution control and sediment remediation strategies in other polluted rivers in the world.

\section{Materials and Methods}

\section{Study Area}

The Pearl River Delta (PRD) is formed by the Beijiang River, the Xijiang River, and the Dongjiang River, the three main branches of the Pearl River, which is China's second largest river after the Yangtze in terms of annual average flow. The $\mathrm{PRD}$ is the most economically developed region in China. It is 
also one of the most important manufacturing bases on the world and known as "the World's Factory."

Guangzhou and Foshan are two of the most important cities in the PRD. Guangzhou, in particular, is well-known as an essential city in South China. The two cities are linked by the Foshan Waterway, which is $26.4 \mathrm{~km}$ long (Fig. 1). It flows westward from Shakou Gate, Chancheng District of Foshan, mingles with Pingzhou Waterway in Shawei Bridge, and then runs into the Guangzhou section of the Pearl River (Fig. 1). The Foshan Waterway is the only river that flows through downtown of Foshan City, connecting the two important waters (Beijiang River and the Guangzhou section of the Pearl River). However, in recent decades, large amounts of industrial wastes and domestic sewage have been poured into the Foshan Waterway, which caused serious pollution to Foshan but also spreads the contamination to Guangzhou.

\section{Sampling and Sample Preparation}

Based on a previous pollution investigation and a study of the files provided by the local government, 14 sampling stations (Fig. 1) were selected to represent the sediments in the Foshan Waterway, considering the features of pollution discharge of the river such as the geometric characteristic of the river way, the hydrology, the distribution of pollution sources, and the locations of wastewater outlets (Table 1). Samples were collected in July 2005 using core samplers. The core samples were collected from the left and right banks at each sampling station. In each bank, three undisturbed sediment cores were collected using 60-cm-long Perspex tubes. Each sample was cut in situ into an upper layer $(0$ to $20 \mathrm{~cm})$ and a lower layer $(21$ to $50 \mathrm{~cm})$ and sealed in polyethylene bags. The sealed bags were then transferred to a box with ice. The environmental conditions at the sampling stations were also recorded.
The samples were spread out and placed in a designed airdried shelf in a special room with air conditioners in the laboratory. After 2 weeks, some samples on the shelf were tested and verified to assure the complete evaporation of water (The samples were taken into a dry oven at $105^{\circ} \mathrm{C}$ to test, and the weight difference before and after drying was evaluated). The dried samples were disposed: firstly, the gravel, shells, weeds, and other large materials in the dried samples were removed. Then, the samples were spread on an organic glass, pressed to pass completely through a 20 -mesh $(840 \mu \mathrm{m})$ nylon screen [50]. The sieved samples were divided into 5- to 10-g aliquots via the four cent method, homogenized and ground using an agate mortar, and then passed through a 100-mesh $(150 \mu \mathrm{m})$ nylon screen. The screened samples were stored in a refrigerator.

\section{Sample Analysis and Data Processing}

The prepared sediment samples were digested according to the SW-846 method 3052 [59]. Briefly, about $0.5 \mathrm{~g}$ of each homogenized sediment sample was digested using $12 \mathrm{~mL}$ of aqua regia $(9 \mathrm{~mL} \mathrm{HNO} 3+3 \mathrm{~mL} \mathrm{HCl})$ and $1 \mathrm{~mL}$ of $\mathrm{HF}$ in a Teflon vessel and heated in a microwave oven at $180^{\circ} \mathrm{C}$ for $10 \mathrm{~min}$. The digested solution was diluted to $50 \mathrm{~mL}$ using deionized water (Milli-Q). The same procedure was used for the blank solutions. Spiked samples were also prepared to calculate the recovery rate of the digestion procedure. After filtering the diluted solution, the total concentrations of sedimentary metals $(\mathrm{Fe}, \mathrm{Cu}, \mathrm{Ni}, \mathrm{Pb}, \mathrm{Cr}$, and $\mathrm{Zn}$ ) were determined using flame atomic absorption spectrometry (FLAA, Hitachi Z-5000), whereas $\mathrm{Cd}$ was determined using a Graphite Furnace AA (GFAA, Hitachi Z-5000).

The sediment samples for $\mathrm{Hg}$ and As were processed and determined differently [60]. Briefly, $0.2500 \mathrm{~g}$ samples were
Fig. 1 Locations of Foshan Waterway (including its branches), Beijiang River, Guangzhou section of the Pearl River, and the sampling stations

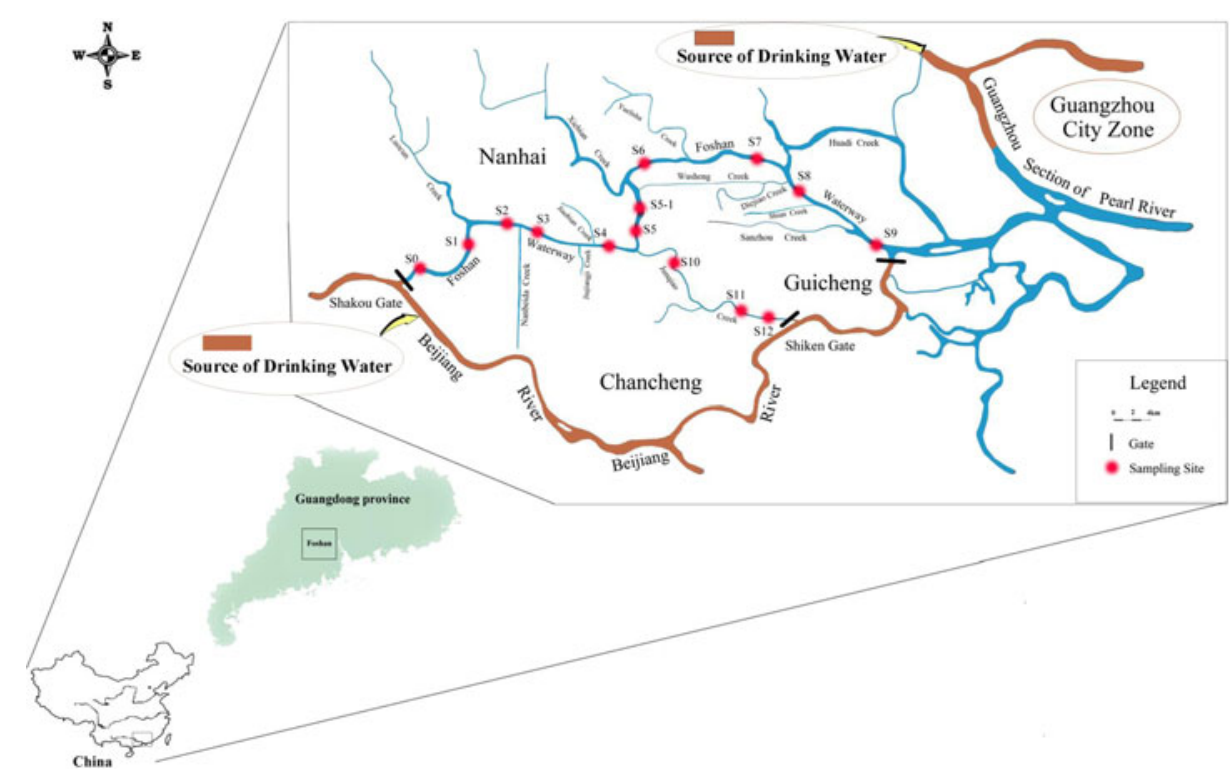


Table 1 Sediment sampling sites at Foshan Waterway

Stations Specific locations Sampling strategy

S0 Upstream Foshan Waterway, near Shakou Gate which is the starting point of the river. The coordinates: $23^{\circ} 2.24^{\prime} \mathrm{N}, 113^{\circ} 1.81^{\prime} \mathrm{E}$

S1

Upstream Foshan Waterway, about 200 m away from the mouth of Luocun Creek.

The coordinates: $23^{\circ} 3.00^{\prime} \mathrm{N}, 113^{\circ} 2.86^{\prime} \mathrm{E}$ )

Upstream Foshan Waterway, between the mouth of Luocun Creek and the mouth of Nanbeida Creek. The coordinates: $23^{\circ} 3.24^{\prime} \mathrm{N}, 113^{\circ} 2.99^{\prime} \mathrm{E}$

Upstream Foshan Waterway, between the mouth of Nanbeida Creek and the mouth of Jiujiangji Creek. The coordinates: $23^{\circ} 3.16^{\prime} \mathrm{N}, 113^{\circ} 4.21^{\prime} \mathrm{E}$

Midstream Foshan waterway, near the mouth of Jiaobian Creek.

The coordinates: $23^{\circ} 3.01^{\prime} \mathrm{N}, 113^{\circ} 5.74^{\prime} \mathrm{E}$

Midstream Foshan Waterway, about 100 m away from the mouth of Junqiao Creek. Downtown Foshan City. The coordinates: $23^{\circ} 2.97^{\prime} \mathrm{N}, 113^{\circ} 6.86^{\prime} \mathrm{E}$

S5-1 Midstream Foshan Waterway, near the mouth of Wusheng Creek.

The coordinates: $23^{\circ} 3.51^{\prime} \mathrm{N}, 113^{\circ} 6.98^{\prime} \mathrm{E}$

Midstream Foshan Waterway, near the mouth of Xiebian Creek.

The coordinates: $23^{\circ} 4.49^{\prime} \mathrm{N}, 113^{\circ} 7.15^{\prime} \mathrm{E}$

Downstream Foshan Waterway, between the mouth of Yuelisha Creek and the mouth of Huadi Creek. The coordinates: $23^{\circ} 4.50^{\prime} \mathrm{N}, 113^{\circ} 9.92^{\prime} \mathrm{E}$

Downstream Foshan Waterway, between the mouth of Diejiao Creek and the mouth of Shian Creek.

The coordinates: $23^{\circ} 4.03^{\prime} \mathrm{N}, 113^{\circ} 10.48^{\prime} \mathrm{E}$

Downstream Foshan Waterway. Near the mouth of Sanzhou Creek.

The coordinates: $23^{\circ} 2.73^{\prime} \mathrm{N}, 113^{\circ} 12.42^{\prime} \mathrm{E}$

Creek.

The coordinates: $23^{\circ} 2.53^{\prime} \mathrm{N}, 113^{\circ} 7.06^{\prime} \mathrm{E}$

Located at the starting point of Foshan Waterway, and water flows from Beijiang River via Shiken Gate. There were no pollution sources nearby based on the results of pollution source investigation. It could serve as the referee site and baseline values could be obtained from the analytical results of sediments collected from the stations.

Influenced by sewage from Luocun Creek which is the main drainage of Luocun town where there are many small factories including electroplate industry, printing and dyeing industry, textile industry, battery and circuit board manufacturing and so on. Water upstream was polluted by industry and domestic wastewater, so it may be the interface of water quality.

Influenced by sewage from Luocun Creek and Nanbeida Creek, which is the main drainage of many dyeing factories. Impacted both by domestic sewage and industrial wastewater. Sewage mainly produced by an intensive residential area located in the right bank of the section of Foshan Waterway. Industrial wastewater mainly produced by the industrial zone located in the left bank of the river including knit dyeing factories, metal jewelry factories

Influenced by sewage from Nanbeida Creek and Jiujiangji Creek. There was an industrial zone near Nanbeida Creek, where there were many factories including metal manufacturing, knitting and ceramics. In addition, there was a coal terminal near this station.

The station located in the bend reach of Foshan Waterway at the edge of Foshan City downtown. The water flow quietly, which facilitates the deposition of trace elements. The station was influenced by wastewater from Jiaobian Creek and Jiujiangji Creek. There were many paint manufacturing factories, printing and dyeing factories, and ceramics factories along the Jiujiangji Creek.

Influenced by domestic wastewater from downtown and sewage from Junqiao Creek, which is the largest creek of the Foshan Waterway. The river turns the corner here, and suspended solids carrying large amounts of pollutants may deposit here. This station was influenced by wastewater produced by electroplating industry, battery manufacturing, mechanical and electrical industry located in the right bank of the Foshan Waterway, and by wastewater produced by cosmetics, rubber manufacturing, leather production located in left bank of Junqiao Creek.

Influenced by the sewage from Wusheng Creek. There were some potential trace element pollution sources along it, such as cotton industry, electroplating industry, electric power industry. It is located near the shoal covered with vast areas of plants where trace elements may subside here.

Influenced by sewage from Xiebian Creek, Wusheng Creek, and Yuelisha Creek. There were some factories along Xiebian Creek, such as aluminum factory, printing and dyeing factory, and some potential trace element pollution sources, such as ceramics, stainless steel industry, located in the coast of Yuelisha Creek.

The shallow water had a slow flow speed and a grassy bank. This station was influenced by sewage from Wusheng Creek and Huadi Creek. There were also some trace element pollution industries, such as non-ferrous metal production, battery manufacturing, electronics manufacturing, located in the left bank of Foshan Waterway.

The broad river with slow flow speed was surrounded by luxuriant plants on the banks. This station was influenced by industry wastewater, which was discharging into the creek, produced by electroplating industry, ceramics and dyeing industry located in the Diejiao Creek basin and Shian Creek basin.

This station was influenced by the sewage from Sanzhou Creek which was an industry area containing the printing and dyeing, textile, glazed tiles industries located in the left bank and a community located in the right bank.

This station was located in the bend of Junqiao Creek where the water flowed flatly and was influenced by the sewage downstream of Junqiao Creek. There were many factories including a clothing factory and leather factory located in the left bank of Junqiao Creek and the electroplating industry, paper mills, printing and dyeing, pottery industry located in the upper reach of Junqiao Creek. 
Table 1 (continued)

\begin{tabular}{lll}
\hline Stations & Specific locations & Sampling strategy \\
\hline S11 & Midstream Junqiao Creek. & $\begin{array}{l}\text { Water with slow flow speed was surrounded by luxuriant plants on the banks. } \\
\text { This station was located in the edge of the old city center in Foshan and } \\
\text { was influenced by the sewage from midstream of Junqiao Creek. The main } \\
\text { pollution of this station was the sewage from the old city and some } \\
\text { industrial wastewater, like ceramics. }\end{array}$ \\
& $\begin{array}{l}\text { There has a Shiken Gate connecting the Beijiang River, located upstream of } \\
\text { Junqiao Creek. The high-quality water from Beijiang river via this gate } \\
\text { S12 }\end{array}$ & $\begin{array}{l}\text { Ulows into Junqiao Creek. Herein, it was polluted less severely and has } \\
\text { better water quality, but a number of lighting industry and the glass industry } \\
\text { The coordinates: } 23^{\circ} 1.64^{\prime} \mathrm{N}, 113^{\circ} 8.37^{\prime} \mathrm{E}\end{array}$ \\
& were also located in the vicinity.
\end{tabular}

placed into 50-mL colorimetric tubes with stoppers, and $10 \mathrm{~mL}$ of aqua regia was poured into each tube. The filled tubes were allowed to stand overnight after vigorous shaking. The tubes were then heated in a thermostat water bath for $3 \mathrm{~h}$, during which, the tubes were shaken every $30 \mathrm{~min}$. Upon cooling, $5 \mathrm{~mL}$ of a solution of thiourea and ascorbic acid was added into the tubes. Then, the tubes were filled with deionized water up to the graduation line, shaken well, and allowed to settle to collect the clear supernatant for further study. A blank control was simultaneously prepared. The total concentrations of $\mathrm{Hg}$ and As were determined using hydride generation-atomic fluorescence spectrometry (Titan AFS8230). Content of organic carbon (OC) was determined as 0.58 times loss on ignition (loss on ignition after heating for $3.5 \mathrm{~h}$ at $\left.550{ }^{\circ} \mathrm{C}\right)[61]$.

The data were processed using SPSS for Windows ver. 11.0 and Excel 2003. Correlation analysis and PCA were conducted using SPSS for Windows ver. 11.0. Prior to analysis, all data were tested for normality using the K-S method (non-parametric analysis of SPSS).

\section{Quality Assurance/Quality Control}

All glassware and plasticware were cleaned by soaking in $10 \% \mathrm{HNO}_{3}(v / v)$ for $24 \mathrm{~h}$, followed by soaking and rinsing with deionized water (Milli-Q). All reagents used in the experiment were at least of analytical grade. The blank, replicate, and spiked samples were analyzed in each batch of sampling.

The analysis results of certified reference material (CRM, GBW07301a) were within the specified range except for $\mathrm{Hg}$ (Pb $103 \%$, Cu 102 \%, Zn 98 \%, Ni 96 \%, Cr 95 \%, Cd $91 \%$, As $109 \%$, and $\mathrm{Hg} 85 \%$ ). The measurement uncertainty of $\mathrm{Hg}$ is $6 \%$ higher than the allowable deviation of CRM $(9 \%)$. The recovery rates of spiked samples ranged from $83 \%$ to $137 \%$ (Pb $110 \%$, Cu 108 \%, Zn $103 \%$, Ni $92 \%$, Cr $107 \%$, Cd $109 \%$, Hg $83 \%$, As $137 \%$ ). Four of them exceeded the allowable deviation of CRM (Cu $1 \%$ higher, $\mathrm{Cr} 2 \%$ higher, $\mathrm{Hg} 8 \%$ higher, and As $22 \%$ ). The results of spiked samples were not so good especially as far as As was concerned.

\section{Results and Discussion}

\section{The Features of Pollution Discharge of the River}

Foshan Waterway, with steady banks, concrete or rock constructed revetment, is merely eroded. The sediments in the waterway mainly come from sedimentation of the suspended particles in wastewater. As a result, the distribution of sediment contaminants has a close relationship with the pollution discharge conditions along banks nearby including the locations of pollution source, discharge quantity and directions and so on. Because of the tide, the river flows relatively slow and the pollutants in the water move a short distance along downstream. The sediments from downstream (of importance because sometimes countercurrent happens to be influenced by the tide) and upstream make a pollution discharge record on relevant catchment areas. They should be sampled and studied in order to report the regional pollution discharge and find the main pollution sources.

The pollution discharge in the study region is characterized by an important feature: at first, most sewage of the catchment area discharge into the branches (creeks) of the Foshan Waterway then run into the waterway through water gates, which connect the creeks and Foshan Waterway. Therefore, those gates are practical sewage draining exits. There are 12 main branches (also 12 main gates) along the Foshan Waterway: Junqiao Creek, Nanbei Creek, Jiaobian Creek, Jiujiangji Creek, Luocun Creek, Hongxing Creek, Xiebian Creek, Yuelisha Creek, Diejiao Creek, Huadi Creek, Wusheng Creek, Shian Creek, and Sanzhou Creek (Fig. 1). To reflect the real situations of pollution, the sampling stations should locate near those gates. Besides, some factors such as the width and curve changes of river bays and special reaches have been taken consideration. For instance, there is a shoal between the Renmin Bridge and Xiedie Bridge along the Foshan Waterway, which broadens suddenly and slows down the flow speed causing plentiful aquatic particle sedimentation. In addition, the shoal is covered with a vast area of plants and is high in organic matter due to the decayed leaves. In this 
way, lots of trace elements may subside here and it deserves a sample station (This is why station S5-1 was added).

The sampling stations were set mainly according to the features of pollution discharge of the river (Foshan Waterway), as can be seen in Fig. 1 and Table 1.

The Concentrations of Trace Elements and Ecological Risk Assessment

Concentrations of trace elements and $\mathrm{OC}$ in sediments are given in Fig. 2. The results were compared with those of similar studies at home and abroad. The comparison between the present concentrations and those in the literature indicated that the concentrations in the Foshan Waterway were higher (Table 2). Hg was the most prominent among the eight trace metals. The average Hg concentrations in this study were ten times higher than those in the sediments from the Lan-yang River [53] and Erh-jen River [53]. Likewise, the average Cd and $\mathrm{Cr}$ concentrations in this study were five times higher than those in the sediments from the Seyhan Dam [48], Yangtze River [49], Lan-yang River, and Erh-jen River. $\mathrm{Pb}, \mathrm{Cu}, \mathrm{Zn}$, and $\mathrm{Ni}$ were also three to four times higher than in the sediments from other regions. The $\mathrm{Cu}$ concentrations were close to those in the sediments from the Lan-yang River and Erh-jen River. As shown in the aforementioned comparisons, the Foshan Waterway is severely polluted.

The threshold effect levels (TEL) and the probable effect levels (PEL) were used to assess sediment ecosystem health, and it was reported that the biological toxic effects may be absent when the heavy metal content was below the TEL, whereas at heavy metal content higher than the TEL, biological toxic effects often occur, and episodic toxic effects occur when the heavy metal content ranges from TEL to PEL [64]. The trace element concentrations in the Foshan Waterway sediments were compared with elements in sediments obtained in other research, also with TEL and PEL (Fig. 2; Table 2), and the results indicate that $\mathrm{Pb}, \mathrm{Cu}, \mathrm{Zn}, \mathrm{Ni}$, and $\mathrm{Cd}$ in the Foshan Waterway may cause the risk of toxic effects.

Enrichment factor (EF) is one of the indicators most often used for estimating anthropogenic inputs [38, 46, 47]. Using this technique, the sediment $\mathrm{EF}$ ratio can be used as a pollution index by comparing the concentrations of selected metals to the background levels of metals in sediments or suspended particulate matter from local or worldwide rivers. The advantage using measurement concentration of local sediments as the background values is that they can be better for comparison. The widely used elements for normalization are $\mathrm{Al}$ [49, $63]$ and $\mathrm{Fe}[40,48]$. In this study, $\mathrm{Fe}$ was used as a conservative element to differentiate natural from anthropogenic components. In the polluted river, baseline values were obtained from the analysis of sediments collected from station S0, which is located upstream (lightest polluted area) of the river (Fig. 1). In station S0, the high-quality water flows from
Beijiang River via Shiken Gate, and there are no pollution sources nearby. The concentrations of various elements in station S0, shown in Fig. 2, were almost the lowest among those sampling stations.

The element EF is defined as follows:

$\mathrm{EF}=\frac{\left(\frac{M_{\text {sample }}}{F e_{\text {sample }}}\right)}{\left(\frac{M_{\text {baseline }}}{F e_{\text {baseline }}}\right)}$,

where $M_{\text {sample }}$ is the concentration of the examined metal in the examined sediment, $\mathrm{Fe}_{\text {sample }}$ is the concentration of the reference metal in the examined sediment, $M_{\text {baseline }}$ is the concentration of the examined element in station S0, and $\mathrm{Fe}_{\text {baseline }}$ is the concentration of the reference element in station S0.

The calculation results of EF in polluted sediments of the river and grading of pollution based on EF are shown in Fig. 3 . $\mathrm{Hg}$ had the highest EF among the eight elements studied, the upper layer in all stations (except S5-1) have reached extremely severely polluted levels according to the grading standards [65]. Based on the EF values, the degrees of metal pollution are in the following order: $\mathrm{Hg}>\mathrm{Cr}>\mathrm{Zn}>\mathrm{Cu}>\mathrm{Cd}>\mathrm{As}>\mathrm{Pb}>$ $\mathrm{Ni}$. It was noted that the maximum values of $\mathrm{Cr}, \mathrm{Zn}, \mathrm{Cu}, \mathrm{Cd}$, $\mathrm{Pb}$, Ni appeared in the lower layers (Fig. 3), and the EF values of the lower layers were higher than the upper layers in most stations (S3, S4, S5, S5-1, S8, S9, S10, and S12). Lower sediment layers present the past pollution discharge. According to the study of Lin et al. [66], the deposition rate of those waters near to Foshan Waterway is about $4 \sim 5 \mathrm{~cm} \mathrm{a}^{-1}$. So it is deduced that lower sediment layers have reached a height of at least $20 \mathrm{~cm}$ during the past 4 or 5 years, which also reflects the pollution discharge 4 or 5 years ago. The content of lower sediment layers were higher than baseline values except for $\mathrm{Ni}$ and As in some stations, and the highest $\mathrm{EF}$ value of the lower sediment layer reached $42.10(\mathrm{Hg}$, station S5). We can consequently draw a conclusion that a huge number of trace elements has accumulated in surface as well as bottom sediments during the past years.

Although EF may reflect the accumulation of trace elements in sediments through a comparison with the background values, it could not directly reflect the trace element ecological risks. This flaw could be partially compensated by the Hakanson potential ecological risk index which describes the ecological risk index using the weighted sum on the ecological toxicity index of sedimentary enrichment and the related trace elements for evaluation [37]. Hakanson's method is often used in ecological risk assessment as a diagnostic tool to determine the many possible avenues towards a potential ecological risk index, i.e., to sort out which drainage area, reservoir, and substances should be given special attention 

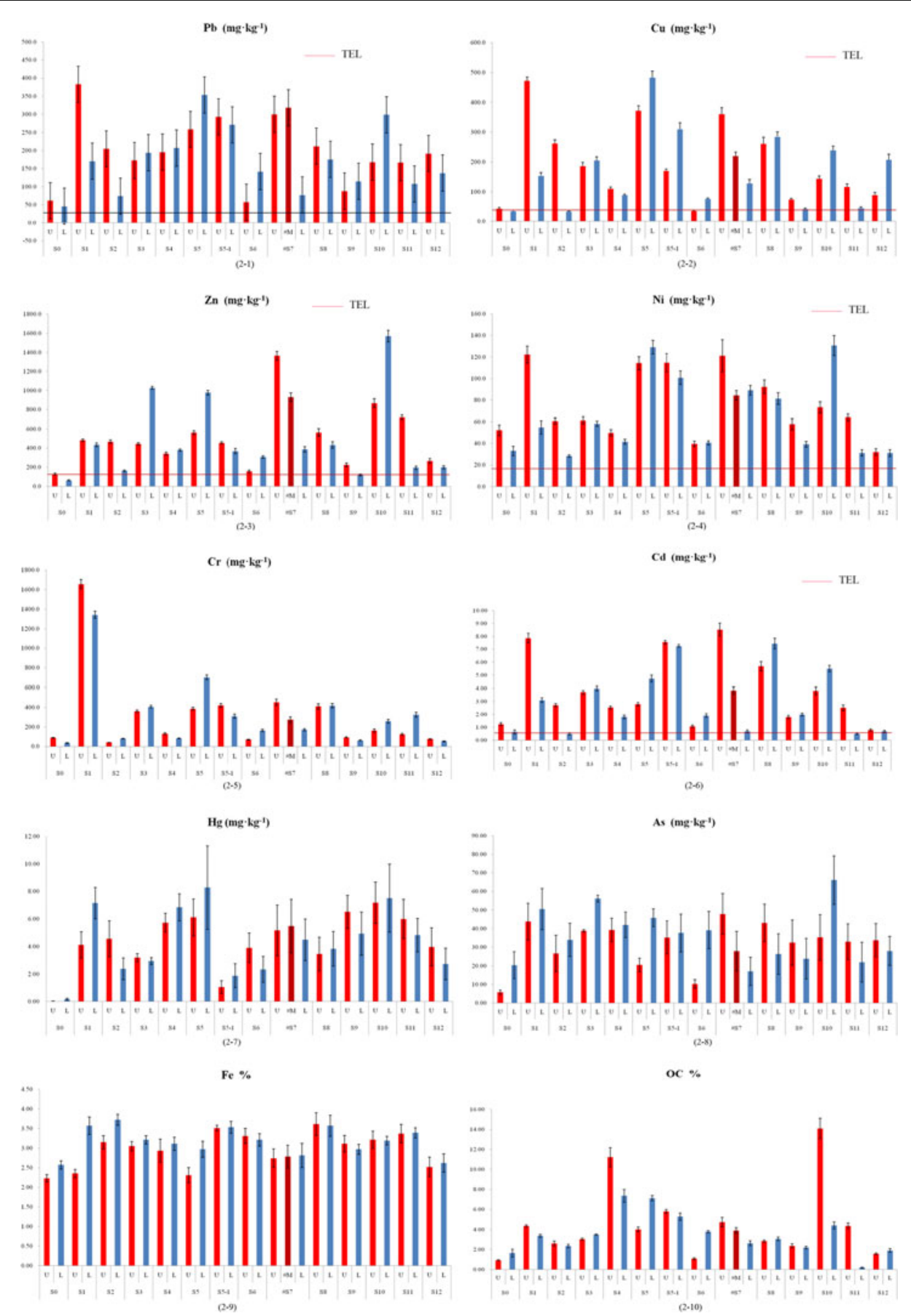

Fig. 2 Concentrations of trace elements and organic carbon $(O C)$ in sediments and the comparison with TEL (threshold effects level) of $\mathrm{Pb}, \mathrm{Cu}, \mathrm{Zn}, \mathrm{Ni}$, and $\mathrm{Cd}[64]$

[50]. It is recognized as a relatively comprehensive method because it considers factors such as the toxicity of different trace elements, the bioavailability of the different trace elements, and the discrepancy of regional background levels of trace elements [67].

The formula for potential ecological risk index is as follows:

$\mathrm{RI}=\sum E_{r}{ }^{i}=\sum T_{r}{ }^{i} \times C_{f}{ }^{i}$
$E_{r}^{i}=T_{r}^{i} \times C_{f}{ }^{i}$

$C_{f}{ }^{i}=C_{s}{ }^{i} / C_{n}{ }^{i}$

where RI is the potential ecological risk index (Eq. (2)); $E_{r}{ }^{i}$ is the potential ecological risk index for a certain heavy metal, which can be calculated using Eq. (3); $T_{r}{ }^{i}$ is the toxicity coefficient that reflects the toxicity of trace elements and 


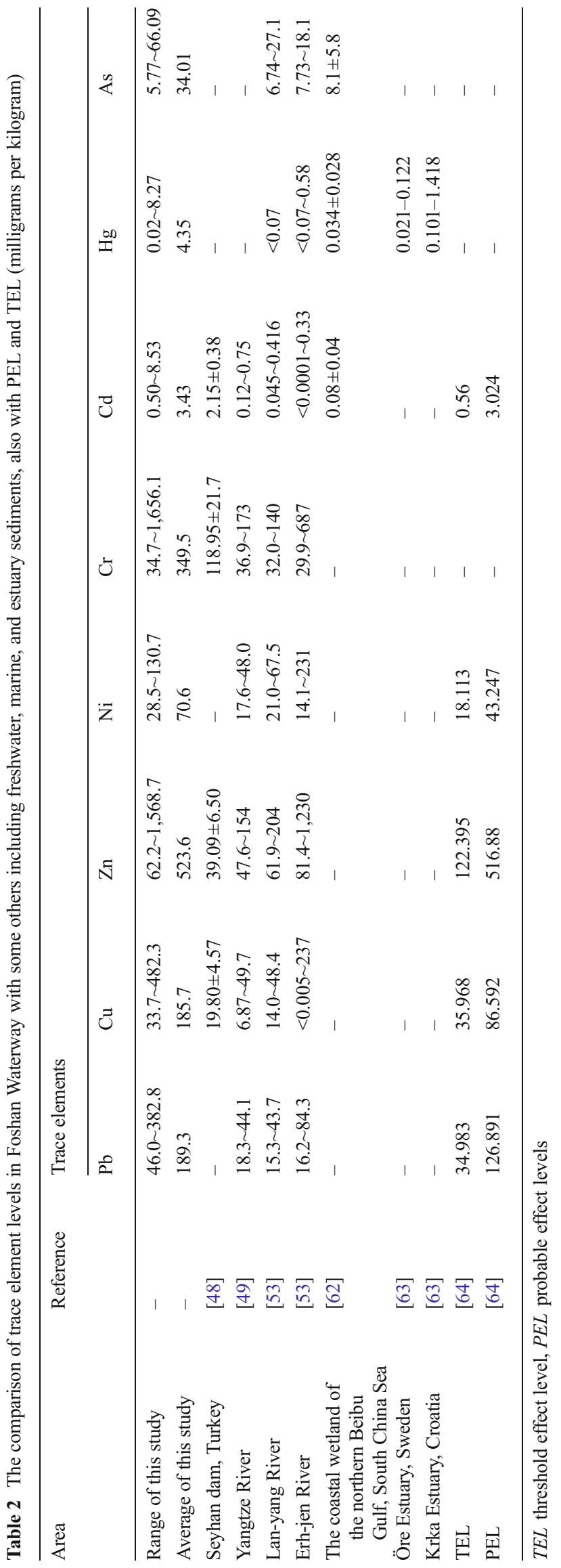

sensitivity to trace elements (Table 3) [37]; $C_{f}^{i}$ is the pollution coefficient of a single metal, calculated using Eq. (4); $C_{s}{ }^{i}$ is the measured level of sedimentary trace elements; $C_{n}{ }^{i}$ is the background level of sedimentary trace elements (obtained from station S0). Among the several trace elements, the top three are $\mathrm{Hg}, \mathrm{Cd}$, and $\mathrm{As}$ (Table 3). They are greatly harmful to ecosystems because of their high toxicity, persistence, and bioaccumulation [68], especially as far as $\mathrm{Hg}$ is concerned. $\mathrm{Hg}$ was well-known as a hazardous contaminant by Minamata disease. In Japan, 2,252 people have been affected and 1,043 have died due to Minamata disease for the past two decades, caused by elevated mercury pollution from a chemical plant [69].

The RIs of the sedimentary trace elements in the Foshan Waterway were shown on Fig. 4. The RI levels in all sampling stations (except for S0 which was the reference site) exceeded 600 (Fig. 4), which may cause severe ecological harm according to the evaluation standards [37, 50, 67]. The highest level in the samples from stations S5 and S10 reached 3,790 and 3,470 , respectively. It was noted that in the six stations (S1, S4, S5, S5-1, S8, S10), the RI levels in the lower layer samples were higher than those in the upper layer, and all levels exceeded 1,000. Furthermore, the peak values appear in the lower layer sample, indicating that the bottom sediments (depth $>20 \mathrm{~cm}$ ) have also been heavily polluted and the potential ecological risk was unacceptable. In this study, RIs were also calculated by summing the RI values of each station with a view to comparing ecological risks of various elements (Fig. 5). It was shown from Fig. 5 that the RI values of $\mathrm{Hg}$ were higher than the other elements. $\mathrm{Cd}$ came in second place and the sequence for the hazardous level is $\mathrm{Hg}>\mathrm{Cd}>\mathrm{As}>\mathrm{Cu}>$ $\mathrm{Pb}>\mathrm{Cr}>\mathrm{Zn}$.

It is worth mentioning that RI is defined considering the comprehensive ecological impact of various trace elements, but chemical species have not been concerned specifically. Chemical species of trace elements may modify in sediments after deposition, modifying the ecological and human risk, the transference, bioaccumulation and biomagnification patterns, and having the chance to be mobilized to the water column and redistributed in the aquatic system. This is typical for $\mathrm{Hg}$, which is mostly released in inorganic form $\left(\mathrm{Hg}^{2+}\right)$ but methylated to methyl mercury ( $\mathrm{MeHg}$ ) in anoxic sediments, which is the most toxic form of mercury. In aquatic systems, even very low concentrations of $\mathrm{MeHg}$ may cause high levels of mercury bioaccumulation in fish or benthic fauna through food chain, increasing dramatically the risk for humans [70] [71].

\section{Pollution Source Identification}

Trace elements may come from natural weathering and erosion, or many other individual pollution sources such as dust, rainfall, water interchange, polluted overlying water, domestic 

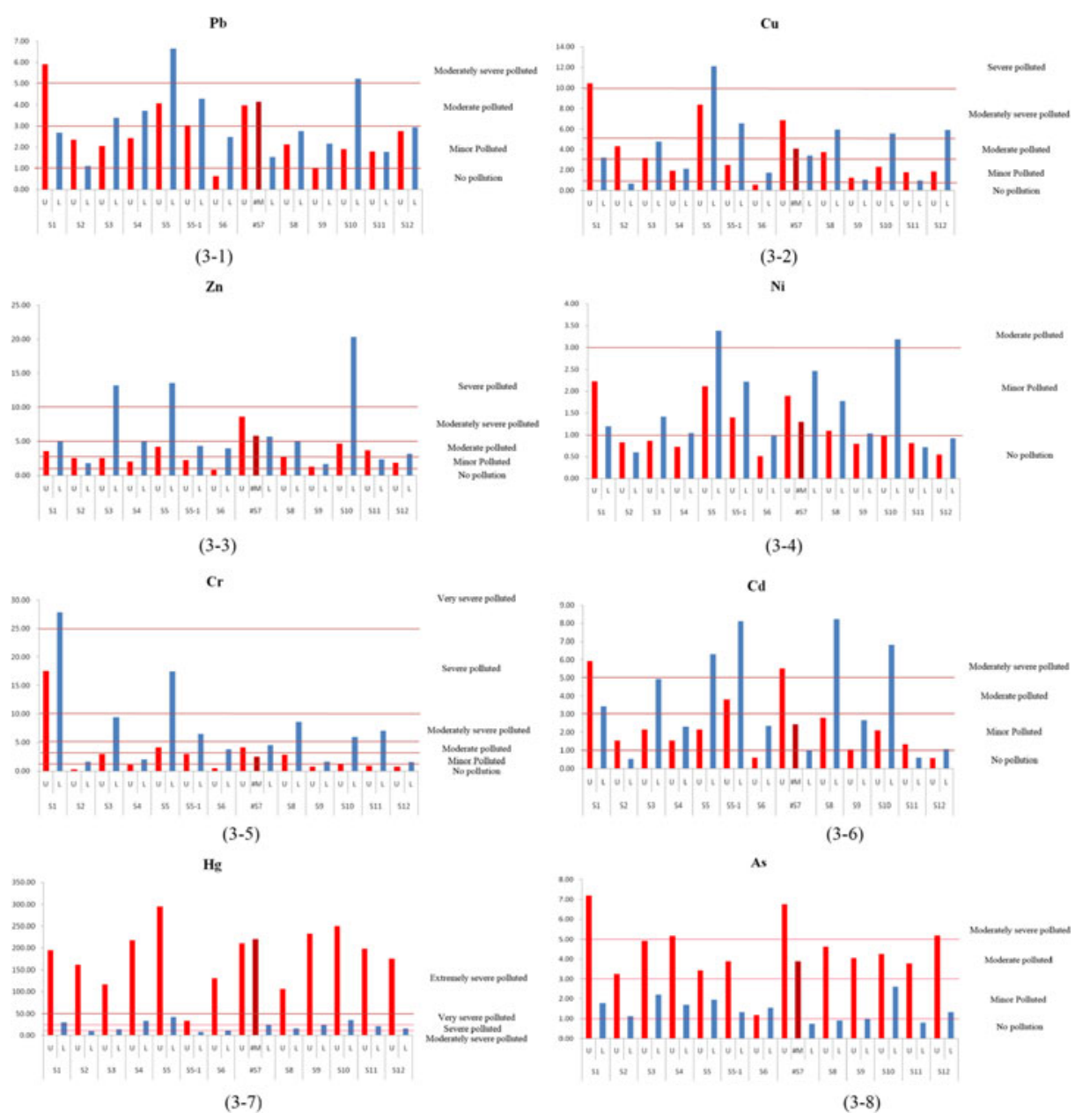

Fig. 3 Enrichment factors $(E F)$ calculated for trace elements $\mathrm{Pb}, \mathrm{Cu}, \mathrm{Zn}, \mathrm{Ni}, \mathrm{Cr}, \mathrm{Cd}, \mathrm{Hg}$, and As in polluted sediments of Foshan Waterway and the evaluation results of pollution grading [65] based on EF

sewage, agricultural and industrial sewage, and so on. Although Foshan is an important industrial city of China, there is only limited data about industrial pollution discharge in the last few years, even worse the data are still incomplete. Actually, the list does not include many enterprises which discharge severely, and even the listed enterprises do not declare the real discharge amount. Multivariate statistical analysis helps identify the sources of contaminants [46, 52, 55]. Principal component analysis (PCA), a method for handling inconsistencies, reflects most information of multivariable origin by simplifying statistics, which means employing less comprehensive indices instead of more relative indices [53]. Given this advantage, PCA is frequently used to analyze the sources of sedimentary trace

Table 3 The toxicity coefficient $\left(T_{r}{ }^{i}\right)$ that was used to calculate Hakanson potential ecological risk index [37]

\begin{tabular}{llllllll}
\hline & $\mathrm{Cr}$ & $\mathrm{Cu}$ & $\mathrm{Zn}$ & $\mathrm{Pb}$ & $\mathrm{As}$ & $\mathrm{Hg}$ & $\mathrm{Cd}$ \\
\hline$T_{r}{ }^{i}$ & 2 & 5 & 1 & 5 & 10 & 40 & 30 \\
\hline
\end{tabular}

elements $[52,54]$. Therefore, it is essential to make inference combined with measured data so as to find the pollution sources.

Figure 2 shows the sedimentary trace elements and OC contents in the Foshan Waterway. The statistics was checked using the K-S method of SPSS to analyze the geographic distribution. Pearson's correlation was used to analyze eight trace elements and OC (Table 4). As shown in Table 4, Pb, Cu, $\mathrm{Ni}, \mathrm{Cd}$, and As have distinct correlations with each other, which proves that these five contaminant trace elements may be discharged from the same sources. Hg was hardly correlated with other metals except $\mathrm{Zn}$, indicating that $\mathrm{Hg}$ is different

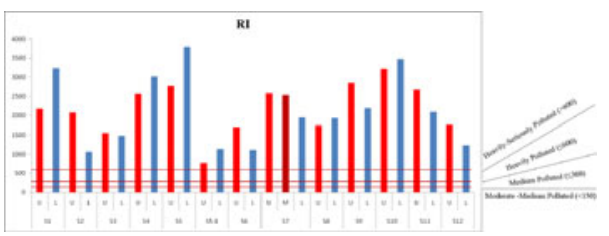

Fig. 4 Hakanson potential ecological risk index $(R I)$ in the sampling stations and the grading of pollution based on RI [37, 50, 67] 
$\operatorname{lgRI}$

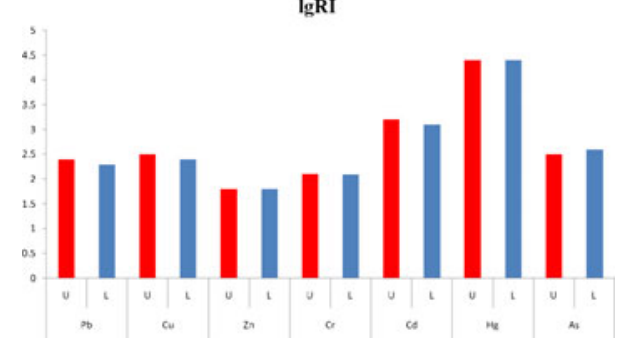

Fig. 5 Hakanson potential ecological risk index $(R I)$ for each element (firstly, RI values have been calculated by summing the RI values of each station with a view to comparing ecological risks of various elements, then they were taken with the logarithm)

from other metals. OC played a totally different role depending on the heavy metal considered. $\mathrm{Pb}, \mathrm{Zn}, \mathrm{Hg}$, As, and $\mathrm{OC}$ were greatly correlated at $p<0.05$, whereas the other four metals were not correlated with OC. The KMO checking coefficient was $0.780<1$, and the concomitant probability of Bartlett test was less than significance level 0.05. Hence, the data from this study is suitable for the factor analysis.

Table 5 and Fig. 6 show the results of PCA analysis. According to Table 5, the two principal components reflect $70.862 \%$ of the information of nine sedimentary variables, i.e., analyzing two principal components providing the majority of the information. The contribution of the first principal component is $44.263 \%$, and the main feature is that factor variables have a high positive load in the concentrations of $\mathrm{Pb}$, $\mathrm{Cu}, \mathrm{Ni}, \mathrm{Cr}$, and $\mathrm{Cd}$. Surveys on contaminant sources indicate that trace elements are mainly from industrial sewage. Consequently, based on the contribution of five metals to the first principal component, the first principal component reflects the trace element pollution from industrial pollution to sediments. In Table $4, \mathrm{~Pb}, \mathrm{Cu}, \mathrm{Ni}, \mathrm{Cr}$, and $\mathrm{Cd}$ are closely correlated, which indicates that the first principal component dominates the sources of $\mathrm{Pb}, \mathrm{Cu}, \mathrm{Ni}, \mathrm{Cr}$, and $\mathrm{Cd}$ in sediments. The contribution of the second principal component is $26.598 \%$, and the high load on OC reaches 0.757 , showing that $\mathrm{OC}$, as metal ion conjugates, are of great importance (Table 5). In addition, Table 5 shows the high load of the second principal component in $\mathrm{Hg}, \mathrm{As}, \mathrm{Pb}$ and $\mathrm{Zn}$, which are
Table 5 The two principal components that reflect most of the information of nine sedimentary variables

\begin{tabular}{lll}
\hline & $\begin{array}{l}\text { Principal } \\
\text { component } 1\end{array}$ & $\begin{array}{l}\text { Principal } \\
\text { component 2 }\end{array}$ \\
\hline Characteristic value & 3.984 & 2.394 \\
Contribution rate \% & 44.263 & 26.598 \\
Accumulative contribution rate \% & 44.263 & 70.862 \\
Load of $\mathrm{Pb}$ & 0.832 & 0.405 \\
Load of $\mathrm{Cu}$ & 0.888 & 0.197 \\
Load of $\mathrm{Zn}$ & 0.515 & 0.674 \\
Load of $\mathrm{Ni}$ & 0.849 & 0.294 \\
Load of $\mathrm{Cr}$ & 0.728 & 0.010 \\
Load of Cd & 0.881 & 0.169 \\
Load of $\mathrm{Hg}$ & 0.041 & 0.820 \\
Load of As & 0.447 & 0.615 \\
Load of $\mathrm{OC}$ & 0.092 & 0.757 \\
\hline
\end{tabular}

all correlated with OC (As shown in Table 4). Accordingly, the second principal component reveals the contribution of OC to sedimentary trace elements accumulation. Among the four elements, $\mathrm{Hg}$ has the highest load (0.820), and the highest correlation coefficient $(0.444)$ with OC. Consequently, the second principal component mainly dominates the sources of $\mathrm{Hg}$ and partly dominates the sources of $\mathrm{As}, \mathrm{Zn}$, and $\mathrm{Pb}$.

Figure 6 also helps describe the two-dimensional load of each contaminant. The degree of dispersion among each element directly reflects two factors that influence the trace elements in the Foshan Waterway sediments: industrial sewage and the complexation and absorption of OC. Many researchers consider that directly discharging organic sewage into rivers and lakes is the main method by which organic content increases in polluted river and lake sediments $[8,30$, $48,53]$. Organic sewage includes domestic sewage and tertiary industry sewage, as well as industrial sewage. Therefore, the second principal component suggests the influence of domestic and industrial sewage to trace elements accumulation, that is, the fundamental reason for the trace elements
Table 4 Correlation coefficient matrix of the trace elements and organic carbon in sediments of Foshan Waterway

${ }^{*} p<0.05 ; * * p<0.01$

\begin{tabular}{llllllllll}
\hline & $\mathrm{Pb}$ & $\mathrm{Cu}$ & $\mathrm{Zn}$ & $\mathrm{Ni}$ & $\mathrm{Cr}$ & $\mathrm{Cd}$ & $\mathrm{Hg}$ & $\mathrm{As}$ & $\mathrm{OC}$ \\
\hline $\mathrm{Pb}$ & 1.000 & & & & & & & \\
$\mathrm{Cu}$ & $0.836^{* *}$ & 1.000 & & & & & & & \\
$\mathrm{Zn}$ & $0.659^{* *}$ & $0.556^{* *}$ & 1.000 & & & & & \\
$\mathrm{Ni}$ & $0.795^{* *}$ & $0.819^{* *}$ & $0.689^{* *}$ & 1.000 & & & & \\
$\mathrm{Cr}$ & $0.552^{* *}$ & $0.600^{* *}$ & 0.221 & $0.481^{* *}$ & 1.000 & & & \\
$\mathrm{Cd}$ & $0.765^{* *}$ & $0.733^{* *}$ & $0.569^{* *}$ & $0.796^{* *}$ & $0.533^{* *}$ & 1.000 & & \\
$\mathrm{Hg}$ & 0.353 & 0.277 & $0.498^{* *}$ & 0.290 & 0.210 & 0.062 & 1.000 & & \\
$\mathrm{As}$ & $0.592^{* *}$ & $0.407^{*}$ & $0.672^{* *}$ & $0.400^{*}$ & $0.421^{*}$ & $0.509^{* *}$ & $0.396^{*}$ & 1.000 & \\
$\mathrm{OC}$ & $0.398^{*}$ & 0.229 & $0.380^{*}$ & 0.308 & 0.075 & 0.319 & $0.444^{*}$ & $0.381 *$ & 1.000 \\
\hline
\end{tabular}




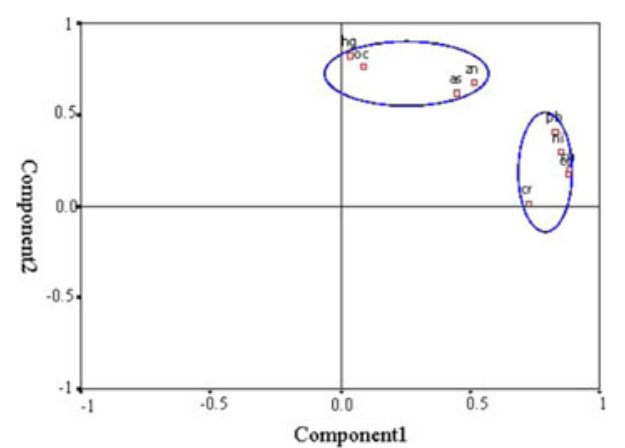

Fig. 6 The two principal components calculated by PCA reflecting the relationship of eight trace elements and OC

accumulation in the Foshan Waterway sediment is the discharge of domestic and industrial sewage, which hastens the accumulation of trace elements. These results are consistent with the pollution discharge features in this area: wastewater (mixed with domestic and industry sewage) were all discharged into the creeks, and then flowed into the Foshan Waterway.

To further understand the pollution discharge situations and identify the main pollution sources of trace elements, the analysis results of PCA were integrated with data gained from the local Environmental Protection Agency. $\mathrm{Hg}$ is one of the most toxic trace elements in the environment and represents a global contamination problem [70, 71]. $\mathrm{Hg}$ and compounds within it all are highly toxic chemicals, which can gradually store up in the human body via the food web. Natural sources of $\mathrm{Hg}$ are mainly from atmospheric deposition including volcanic emissions and forest fires. Potential anthropogenic $\mathrm{Hg}$ sources include insecticides, fungicides, electrical equipment, paint, plastics, cosmetics, anti-fouling and mildew-proofing paints, phosphate fertilizers, batteries, fireworks. According to the analysis of information from the local environmental protection agency and the experimental results, it is concluded that $\mathrm{Hg}$ pollution in the Foshan Waterway is caused by certain industries such as cosmetics, electrical equipment, and battery. The pollution sources of $\mathrm{Hg}$ are located in the Foshan Waterway and Jiaobian Creek coast (Fig. 7; 2). Similarly, it can be concluded that $\mathrm{Cd}$ pollution results from the industries including non-ferrous metal production, refuse incineration, sewage sludge, insecticides and batteries. And its pollution sources lie on the Foshan Waterway and Wusheng Creek coast (Fig. 7; 3). And industries like leather, pesticides, and pharmaceutical result in As pollution, whose sources are along the Junqiao Creek (Fig. 7; 4). Industries such as metal plating, brake lining wear, fungicides, insecticides, rubber, and phosphate fertilizers lead to $\mathrm{Cu}$ pollution, whose sources are in Jiujiangji Creek and Junqiao Creek (Fig. 7; 2). In addition, the pollution sources of $\mathrm{Pb}$ and $\mathrm{Cr}$ are along the Luochun Creek (Fig. 7; 1). And the pollution sources of $\mathrm{Zn}$ and $\mathrm{Ni}$ are in the downstream of Junqiao Creek (Fig. 7; 4).

\section{Conclusion}

Foshan Waterway is severely polluted with trace elements, both the surface sediments $(0$ to $20 \mathrm{~cm})$ and the bottom sediments (21 to $50 \mathrm{~cm}$ ) being contaminated. $\mathrm{Hg}$ is the most serious pollutant. Industrial sewage is the fundamental source of high concentrations of trace elements in river sediments, and organic matter from domestic wastewater hastens the accumulation of those trace metals. If from the perspective of the high ecological risk only, further dredging is probably essential. Above all, it must be prohibited that both industrial wastewater and domestic sewage are discharged into the rivers.
Fig. 7 Potential pollution sources of $\mathrm{Hg}, \mathrm{Cd}, \mathrm{As}, \mathrm{Cu}, \mathrm{Pb}, \mathrm{Zn}, \mathrm{Ni}$, $\mathrm{Cr}$ were identified by way of integrating the analysis results of PCA and data gained from the local government. Red arrows refer to the direction of water when the seawater is at high tide; black arrows refer to the direction of water when the seawater is at low tide

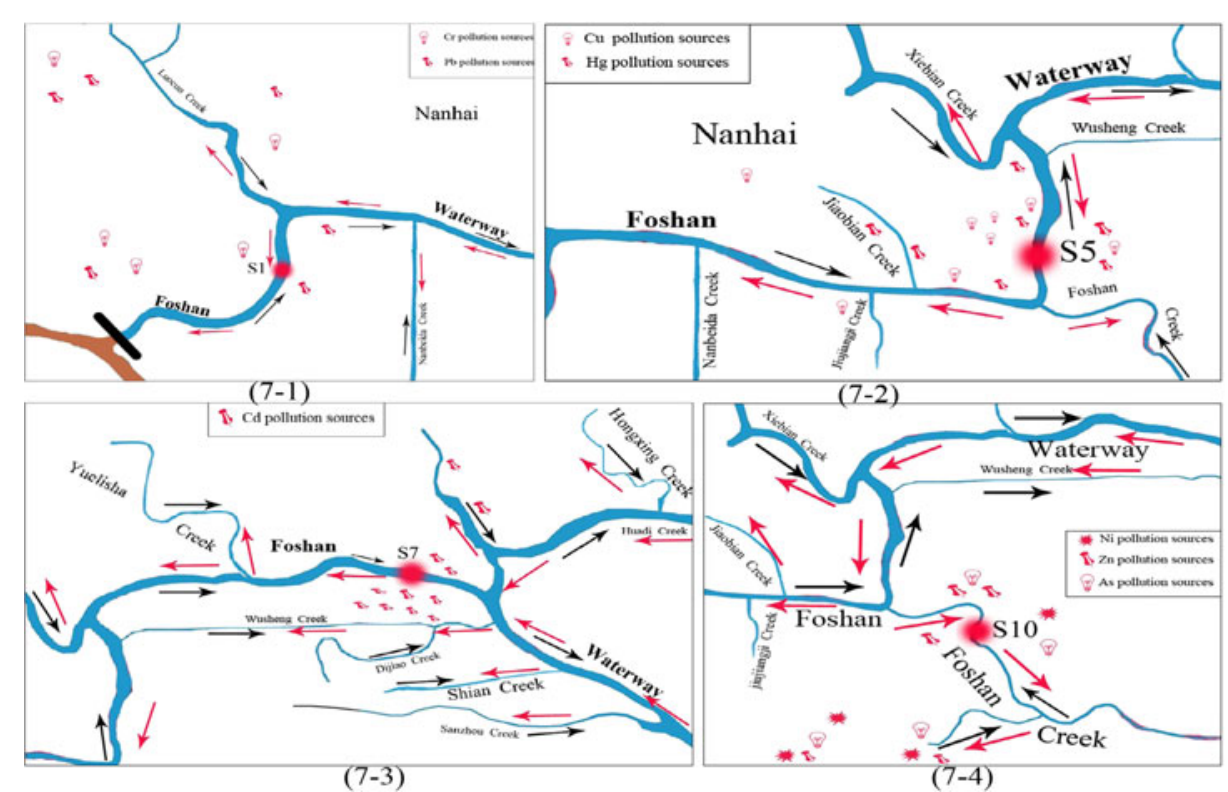


Acknowledgments Thank for the Project Management Office of Second Pearl River Delta Urban Environment Project (PRD2)-Foshan Subproject, and the help of Xian-ge Wei, Shu-you He, Lei Zhang, Guang-hui Yu. This work was partly founded by the National Natural Science Foundation of China (no. 41001341) and Nature Science Foundation of Guangdong Province, China (no. 9151401501000015).

Open Access This article is distributed under the terms of the Creative Commons Attribution License which permits any use, distribution, and reproduction in any medium, provided the original author(s) and the source are credited.

\section{References}

1. Harikumar PS, Nasir UP (2010) Ecotoxicological impact assessment of trace elements in core sediments of a tropical estuary. Ecotoxicol Environ Saf 73:1742-1747

2. Demirak A, Yılmaz F, Tuna A, Levent T, Nedim O (2006) Heavy metals in water, sediment and tissues of Leuciscus cephalus from a stream in southwestern Turkey. Chemosphere 63:1451-1458

3. De Jonge M, Belpaire C, Geeraerts C, De Cooman W, Blust R, Bervoets L (2012) Ecological impact assessme nt of sedimen $t$ remed iation in a metal-contaminated lowland river using translocated zebra mussels and resident macroinvertebrates. Environ Pollut 171:99-108

4. Ribeiro Guevara S, Bubach D, Vigliano P, Lippolt G, Arribere M (2004) Heavy metal and other trace elements in native mussel Diplodon chilensis from Northern Patagonia Lakes, Argentina. Biol Trace Elem Res 102:245-263

5. Shahram E, Akbar HM, Naser J, Seyed FN, Seyed MN, Mohammad Ali E (2011) Trace element level in different tissues of Rutilus frisii kutum Collected from Tajan River, Iran. Biol Trace Elem Res 143:965-973

6. Arribere MA, Ribeiro GS, Bubach DF, Vigliano PH (2006) Trace elements as fingerprint of Lake of Provenance and of species of some native and exotic fish of Northern Patagonian Lakes. Biol Trace Elem Res 111:71-95

7. Lesven L, Lourino-Cabana B, Billon G, Proix N, Recourt P, Ouddane B, Fischer JC, Boughriet A (2009) Water-quality diagnosis and metal distribution in a strongly polluted zone of Deûle river (northern France). Water Air Soil Poll 198:31-44

8. Cukrov N, Franciskovic-Bilinski S, Hlaca B, Barišić D (2011) A recent history of metal accumulation in the sediments of Rijeka harbor, Adriatic Sea, Croatia. Mar Pollut Bull 62:154-167

9. Mario C, Valeria D, Georg H, Stefano P (2012) Guidance for sediment and biotamonitoring under the Common Implementation Strategy for the Water Framework Directive. Trac Trend Anal Chem 36:15-24

10. Icela DBQ, Hugo ESC, Pedro AP, Edgar LG, Sergio GS, Julisa GA (2012) Determination of distributions of $\mathrm{Cd}, \mathrm{Cu}$, and $\mathrm{Pb}$ concentrations in sediments of a Mexican reservoir to infer their environmental risk. Biol Trace Elem Res 148:122-132

11. Hossein P, Zahra A, Parvin F, Mahmood K, Nematullah K, Abdolreza K (2011) Bioavailability and concentration of heavy metals in the sediments and leaves of grey mangrove, Avicennia marina (Forsk.) Vierh, in Sirik Azini Creek, Iran. Biol Trace Elem Res 143:11211130

12. Ana TL, Paula T, Salomé FPA, João XM, Eduardo FDS (2011) Environmental impact of mining activities in the Lousal area (Portugal): chemical and diatom characterization of metalcontaminated stream sediments and surface water of Corona stream. Sci Total Environ 409:4312-4325

13. Windom HL, Schropp SJ, Calder FD, Ryan JD, Smith RG Jr, Burney LC, Lewis FG, Rawlinson CH (1989) Natural trace metal concentration in estuarine and coastal marine sediments of the southeastern Unites State. Environ Sci Technol 23:314-320

14. Yin HB, Fan CX, Ding SM, Zhang L, Zhong JC (2008) Geochemistry of iron, sulfur and related heavy metals in metal-polluted Taihu Lake sediments. Pedosphere 18:564-573

15. Prica M, Dalmacija B, Roncevic S, Krcmar D, Becelic M (2008) A comparison of sediment quality results with acid volatile sulfide (AVS) and simultaneously extracted metals (SEM) ratio in Vojvodina (Serbia) sediments. Sci Total Environ 389:235-244

16. Liu WX, Coveney RM, Chen JL (2003) Environmental quality assessment on a river system polluted by mining activities. Appl Geochem 18:749-764

17. Lourino-Cabana B, Lesven L, Billon G, Proix N, Recourt P, Ouddane B, Fischer JC, Boughriet A (2010) Impacts of metal contamination in calcareous waters of Deûle River (France): water quality and thermodynamic studies on metallic mobility. Water Air Soil Poll 206:187-201

18. Van Griethuysen C, Luitwieler M, Joziasse J, Koelmans AA (2005) Temporal variation of trace metal geochemistry in floodplain lake sediment subject to dynamic hydrological conditions. Environ Pollut 137:281-294

19. Wen XH, Allen HE (1999) Mobilization of heavy metals from Le An River sediment. Sci Total Environ 227:101-108

20. Huang KM, Lin S (2003) Consequences and implication of heavy metal spatial variations in sediments of the Keelung River drainage basin, Taiwan. Chemosphere 53:1113-1121

21. Vicente Martorell JJ, Galindo-Riano MD, García Vargas M, GranadoCastro MD (2009) Bioavailability of heavy metals monitoring water, sediments and fish species from a polluted estuary. J Hazard Mater $162: 823-836$

22. Olivares-Rieumont S, la RD D, Lima L, Grahamb DW, K D' A, Borrotoa J, Martíneza F, Sánchezc J (2005) Assessment of heavy metal levels in Almendares River sediments-Havana City, Cuba. Water Res 39:3945-3953

23. Lepland A, Andersen TJ, Lepland A, Peter HAH, Alve E, Breedveld GD, Rindby A (2010) Sedimentation and chronology of heavy metal pollution in Oslo harbor, Norway. Mar Pollut Bull 60:1512-1522

24. Tam NFY, Wong YS (2000) spatial variation of heavy metals in surface sediments of Hong Kong mangrove swamps. Environ Pollut 110:195-205

25. Qiao S, Yang Z, Pan Y, Guo Z (2007) Metals in suspended sediments from the Changjiang (Yangtze River) and Huanghe (Yellow River) to the sea and their comparison. Estuarine Coastal Shelf Sci 74:539-548

26. USEPA (2005) Procedures for the derivation of equilibrium partitioning sediment benchmarks (ESBs) for the protection of benthic organisms: metals mixtures (cadmium, copper, lead, nickel, silver and zinc), EPA-600-R-02-011, Office of Research and Development. Washington, DC, USA

27. Boughriet A, Proix N, Billon G, Recourt P, Ouddane B (2007) Environmental impacts of heavy metal discharges from a smelter in Deûle-canal sediments (Northern France): concentration levels and chemical distribution. Water Air Soil Poll 180:83-95

28. Zhang L, Ye X, Feng H (2007) Heavy metal contamination in western Xiamen Bay sediments and its vicinity, China. Mar Pollut Bull 54:974-982

29. An YJ, Kampbell DH (2003) Total, dissolved, and bioavailable metals at Lake Texoma marinas. Environ Pollut 122:253-259

30. Evenset A, Christensen GN, Carroll J, Zaborskab A, Bergerc U, Herzkec D, Gregord D (2007) Historical trends in persistent organic pollutants and metals recorded in sediment from Lake Ellasjøen, Bjørnøya, Norwegian Arctic. Environ Pollut 146:196-205

31. Zhang H, Shan B (2008) Historical records of heavy metal accumulation in sediments and the relationship with agricultural intensification in the Yangtze-Huaihe region, China. Sci Total Environ 399:113-120

32. Chatterjee M, Silva Filho EV, Sarkar SK, Sellab SM, Bhattacharyaa A, Satpathyc KK, Prasadc MVR, Chakrabortya S, Bhattacharyaa BD 
(2007) Distribution and possible source of trace elements in the sediment cores of a tropical macro-tidal estuary and their ecotoxicological significance. Environ Int 33:346-356

33. USEPA (2004) The Incidence and Severity of Sediment Contamination in Surface Waters of the United States (National Sediment Quality Survey), EPA-823-R-04-007. Office of Science \& Technology, Washington, DC, USA

34. Hang X, Wang H, Zhou J, Du C, Chen X (2009) Characteristics and accumulation of heavy metals in sediments originated from an electroplating plant. J Hazard Mater 163:922-930

35. Lesven L, Lourino-Cabana B, Billon G, Recourt P, Ouddane B (2010) On metal diagenesis in contaminated sediments of Deûle river (northern France). Appl Geochem 25:1361-1373

36. Tessier A, Campbell PGC, Bisson M (1979) Sequential extraction procedure for the speciation of particulate trace metals. Anal Chem $51: 844-851$

37. Hakanson L (1980) An ecological risk index for aquatic pollution control-a sediment ecological approach. Water Res 14:975-1001

38. Gonzáles-Macías C, Schifter I, Lluch-Cota DB, Méndez-Rodríguez L, Hernández-Vázquez S (2006) Distribution, enrichment and accumulation of heavy metals in coastal sediments of Salina Cruz Bay, Mexico. Environ Monit Assess 118:211-230

39. Barlas N, Akbulut N, Aydoğan M (2005) Assessment of heavy metal residues in the sediment and water samples of Uluabat Lake, Turkey. B Environ Contam Tox 74:286-293

40. Ghrefat $\mathrm{H}$, Yusuf $\mathrm{N}$ (2006) Assessing $\mathrm{Mn}, \mathrm{Fe}, \mathrm{Cu}, \mathrm{Zn}$ and $\mathrm{Cd}$ pollution in bottom sediments of Wadi Al-Arab Dam, Jordan. Chemosphere 65:2114-2121

41. Zheng N, Wang Q, Liang Z, Zheng D (2008) Characterization of heavy metal concentrations in the sediments of three freshwater rivers in Huludao City, Northeast China. Environ Pollut 154:135-142

42. Forough F, Abdolreza K, Seyed MM, Mohammad SM, Parvin F (2011) Development of a New Pollution Index for heavy metals in sediments. Biol Trace Elem Res 143:1828-1842

43. Yang Z, Wang Y, Shen Z, Niu J, Tang Z (2009) Distribution and speciation of heavy metals in sediments from the mainstream, tributaries, and lakes of the Yangtze River catchment of Wuhan, China. J Hazard Mater 166:1186-1194

44. Boughriet A, Recourt P, Proix N, Billon G, Leermakers M, Fischer JC, Ouddane B (2007) Fractionation of anthropogenic lead and zinc in Deûle river sediments. Environ Chem 4:114-122

45. Yu KC, Tsai LJ, Chen SH, Ho ST (2001) Chemical binding of heavy metals in anoxic river sediments. Water Res 35:4086-4094

46. Liu WX, Li XD, Shen ZG, Wang DC, Wai OWH, Li YS (2003) Multivariate statistical study of heavy metal enrichment in sediments of the Pearl River Estuary. Environ Pollut 121(3):377-388

47. Louri no-Cabana B, Lesven L, Charriau A, Billon G, Baghdad O, Boughriet A (2011) Potential risks of metal toxicity in contaminated sediments of Deûle river in Northern France. J Hazard Mater 186:2129-2137

48. Çevik F, Göksu MZL, Derici OB, Findik O (2009) An assessment of metal pollution in surface sediments of Seyhan dam by using enrichment factor, geoaccumulation index and statistical analyse. Environ Monit Assess 152:309-317

49. Zhang W, Feng H, Chang J, Qu J, Xie H, Yu L (2009) Heavy metal contamination in surface sediments of Yangtze River intertidal zone: an assessment from different indexes. Environ Pollut 157:1533-1543

50. Fu C, Guo JS, Pan J, Qi J, Zhou W (2009) Potential ecological risk assessment of heavy metal pollution in sediments of the Yangtze River within the Wanzhou Section, China. Biol Trace Elem Res 129:270-277

51. Viguri JR, Irabien MJ, Yusta I, Soto J, Gómez J, Rodriguez P, Martinez-Madrid M, Irabien JA, Coz A (2007) Physico-chemical and toxicological characterization of the historic estuarine sediments: a multidisciplinary approach. Environ Int 33:436-444
52. Loska K, Wiechula D (2003) Application of principal component analysis for the estimation of source of heavy metal contamination in surface sediments from the Rybnik Reservoir. Chemosphere 51:723733

53. Chang ML, Sun YC, Doong RA, Wu SC, Fu CT (2007) Concentrations and correlations of trace metals in estuarine sediments-interpretation by multivariate statistical analysis and elemental normalization. J Environ Eng Manage 17:143-150

54. Han YM, Du PX, Cao JJ, Posmentier ES (2006) Multivariate analysis of heavy metal contamination in urban dusts of Xi'an, Central China. Sci Total Environ 355:176-186

55. Zhang HG, Cui BS, Zhang KJ (2011) Heavy metal distribution of natural and reclaimed tidal riparian wetlands in south estuary, China. J Environ Sci 23:1937-1946

56. Ujević I, Odžak N, Barić A (2000) Trace metal accumulation in different grain size fractions of the sediments from a semi-enclosed bay heavily contaminated by urban and industrial wastewaters. Water Res 34(11):3055-3061

57. Levinton JS, Pochron ST, Kane MW (2006) Superfund dredging restoration results in widespread regional reduction in cadmium in blue crabs. Environ Sci Technol 40:7597-7601

58. Eggleton J, Thomas KV (2004) A review of factors affecting the release and bioavailability of contaminants during sediment disturbance events. Environ Int 30:973-980

59. USEPA (1996) Microwave Assisted Acid Digestion of Siliceous and Organically Based Matrices. SW-846-3052, Washington, DC

60. State Oceanic Administration (1998) The specification for marine monitoring. Part5: Sediment analysis. GB 17378.5-1998 Standards Press of China, Beijing

61. Van Griethuysen C, Van Baren J, Peeters ETHM, Koelmans AA (2004) Trace metal availability and effects on benthic community structure in floodplain lakes. Environ Toxicol Chem 23:668-681

62. Gan HY, Lin JQ, Liang K, Xia Z (2013) Selected trace metals (As, Cd and $\mathrm{Hg}$ ) distribution and contamination in the coastal wetland sediment of the northern Beibu Gulf, South China Sea. Mar Pollut Bull 66:252-258

63. Kwokal Z, Frančišković-Bilinski S, Bilinski H, Branica M (2002) A comparison of anthropogenic mercury pollution in Kastela Bay (Croatia) with pristine estuaries in Ore (Sweden) and Krka (Croatia). Mar Pollut Bull 44:1152-1169

64. MacDonald DD, Ingersoll G, Berger TA (2000) Development and evaluation of consensus-based sediment quality guidelines for freshwater ecosystems. Arch Environ Con Tox 39:20-31

65. Chen CW, Kao CM, Chen CF, Dong CD (2007) Distribution and accumulation of heavy metals in the sediments of Kaohsiung Harbor, Taiwan. Chemosphere 66(8):1431-1440

66. Lin RF, Min YS, Wei K, Zhang G, Yu F, Yu Y (1998) ${ }^{210} \mathrm{~Pb}$-dating of sediment cores from the pearl river mouth and its environmental geochemistry implication. Geochimica 27:401-411

67. Horst MF (1997) Heavy metal distribution in sediments and ecological risk assessment: the role of diagenetic processes in reducing metal toxicity in bottom sediments. Environ Pollut 97:317-325

68. Ennouri R, Chouba L, Magni P, Kraiem MM (2010) Spatial distribution of trace metals $(\mathrm{Cd}, \mathrm{Pb}, \mathrm{Hg}, \mathrm{Cu}, \mathrm{Zn}, \mathrm{Fe}$ and $\mathrm{Mn}$ ) and oligoelements $(\mathrm{Mg}, \mathrm{Ca}, \mathrm{Na}$ and $\mathrm{K}$ ) in surface sediments of the Gulf of Tunis (Northern Tunisia). Environ Monit Assess 163:229-239

69. Kudo A, Miyahara S (1991) A case history: Minamata mercury pollution in Japan - from loss of human lives to decontamination. Water Sci Technol 23:283-290

70. Conaway CH, Squire S, Mason RP, Flegal AR (2003) Mercury speciation in the San Francisco Bay estuary. Mar Chem 80:199-225

71. Li P, Feng XB, Qiu GL, Shang LH, Li ZG (2009) Mercury pollution in Asia: a review. J Hazard Mater 168:591-601 